\title{
A palynological study of the Acheulian site of Gesher Benot Ya'aqov, Israel
}

\author{
Willem van Zeist $\cdot$ Sytze Bottema
}

Received: 12 November 2007/ Accepted: 4 May 2008/Published online: 12 July 2008

(C) The Author(s) 2008

\begin{abstract}
The results are discussed of the palynological (pollen-analytical) examination of a sediment section in the Hula Valley of northern Israel, with evidence of Acheulian occupation dated to $700,000-800,000$ в.P. In general there is a fair agreement between the palynological data and the wood remains identified from the site, but there are also discrepancies, some of which can be explained and others not. Although relatively well represented in the pollen record, Pinus (pine) most probably did not occur in the Hula area. Some pollen types are thought to have been carried in from hundreds of kilometres away (long-distance transport). Together the pollen and wood evidence suggests that Quercus ithaburensis-Pistacia atlantica (Tabor oakAtlantic terebinth) woodland (open forest) was found in the Hula Valley (other than the lake and marshes) and on the lower reaches of the mountains flanking the valley on both sides. In addition to deciduous Tabor oak, evergreen Kermes oak (Quercus calliprinos) must have been an important component of this woodland. Wild olive (Olea europaea var. oleaster) may also have been quite common here. The suggestion of open forest, with fairly widely spaced trees, is based upon the high non-arboreal pollen frequencies and indicates fairly dry climatic conditions. Various stream-bank trees and shrubs are represented in the
\end{abstract}

Sytze Bottema: Deceased in 2005.

Communicated by T. Litt.

W. van Zeist $\cdot$ S. Bottema

Groningen Institute of Archaeology (GIA),

University of Groningen, Groningen, The Netherlands

W. van Zeist $(\square)$

Wilhelminalaan 9, 9781 CT Bedum, The Netherlands

e-mail:w.zeist@planet.nl pollen and/or wood records, such as Fraxinus (ash), Ulmus (elm), Salix (willow) and Platanus (plane tree). During the period represented by the upper section of the pollen diagram, Cedrus (cedar) must have reached the Hula area, indicating increased humidity. In the steppe-like field layer (undergrowth of the woodland) grasses (Gramineae) must have played a prominent role in addition to a great number of other species. In particular Compositae and Umbelliferae include a large variety of species (many different pollen types). Two Chenopodiaceae maxima, coinciding with Gramineae minima, are thought to be indicative of periods of increased climatic dryness. The local lake and marsh vegetation is fairly well represented in the pollen record, but interpretation in terms of vegetation succession is only possible to some degree. Mention is made here of Trapa natans (water chestnut), the nuts of which were consumed by the Acheulian inhabitants.

Keywords Pollen · Early-/middle-Pleistocene vegetation . Hula Valley · Israel

\section{Introduction}

The site

The present paper deals with the palynological (pollenanalytical) examination of the Acheulian site of Gesher Benot Ya'aqov (GBY) in the Hula Valley of north-eastern Israel (location, Fig. 1). The Hula Valley (with the adjacent Dan Valley) forms the northernmost section of the Dead Sea Rift System, through which early hominids spread from Africa to Asia (and subsequently to Europe). At Gesher Benot Ya'aqov, deposits with evidence of Acheulian occupation are found on both banks of the River Jordan and 
in the river-bed. Between 1989 and 1997, excavations directed by N. Goren-Inbar (Institute of Archaeology, The Hebrew University of Jerusalem, Israel) were carried out at a locality south of the Benot Ya'aqov bridges, on the east bank of the river. A main objective of the excavations was the reconstruction of the environmental conditions at the time of the Acheulian occupation. To that end scholars of various disciplines were invited to contribute to this multidisciplinary research project.

Because of the waterlogged sediment, conditions for palaeo-environmental studies were quite favourable at GBY. In addition to animal bones and lithic artefacts, the excavations yielded substantial numbers of perishable organic remains, such as fossil wood, seeds, fruits and pollen. This might suggest that the sediment had been waterlogged since its deposition. However, as will be discussed below, the pollen evidence points to temporary exposure to the air. In addition, evidence of palaeosols in the lower part of the sediment sequence indicates that there must have been periods when soil formation could take place in lacustrine sediment well above the water level.

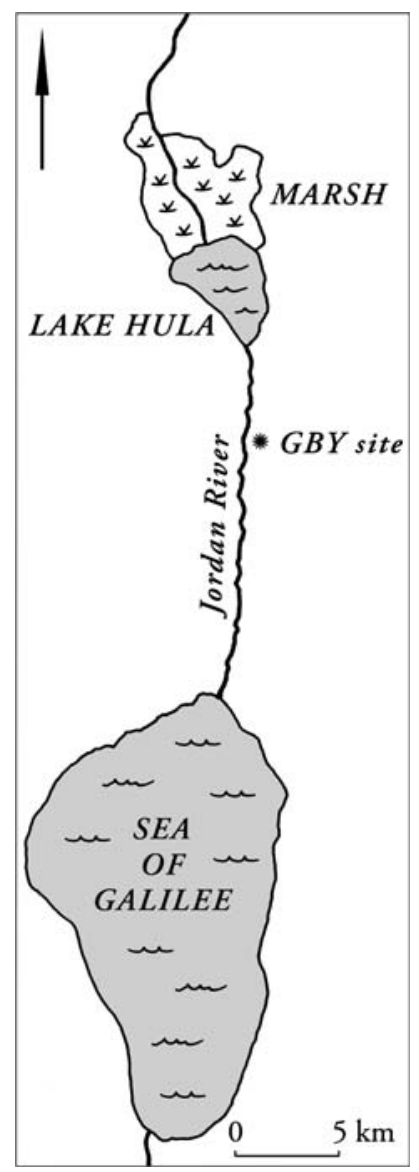

Fig. 1 Location of the Gesher Benot Ya'aqov site excavated through 1989-1997, from which the samples for palynological examination were taken. For more details, see Goren-Inbar et al. (2002b, Fig. 1). Drawing S.E. Boersma (Groningen Institute of Archaeology)
The stratigraphy of the GBY site was examined in six geological trenches (Goren-Inbar et al. 2002b, Fig. 3). The sediment sequence exposed in these trenches has a total thickness of $34.3 \mathrm{~m}$. The top and the base of the sediment section are formed by ca. 3-m-thick conglomerates, deposited during periods of low lake levels when "gravelbed streams transgressed the site" (Rosenfeld et al. 2003, p. 171). The lacustrine beds between the lower and upper conglomerates, to a thickness of some $28 \mathrm{~m}$, consist of alternating layers of littoral (lake-margin) sands and coquinas (shell beds), and offshore muds with molluscs, ostracods, seeds/fruits, charophytes and diatoms. Within the lacustrine sediment sequence five cycles are distinguished, each of which shows a shift from littoral to offshore facies, suggesting lower lake-levels in the early stages of the cycle and higher levels in the later stages. The above information on the site is taken from Goren-Inbar et al. (2002b) and Rosenfeld et al. (2003).

The GBY sediment section, and hence the Acheulian occupation, is roughly dated by the Matuyama-Brunhes Boundary (MBB), the reversed- to normal-polarity transition, which was identified at a depth of $20.2 \mathrm{~m}$ below the top of the upper conglomerate (Goren-Inbar et al. 2000). The date of ca. 780,000 years B.P. for this boundary suggests a period of ca. 700,000-800,000 years ago for the formation of the sediment sequence and the multiple earlyhominid occupations of the site. Some 13 archaeological horizons are recognized in the GBY deposits (N. GorenInbar, personal communication).

\section{Materials and methods}

Samples for palynological examination were collected by Craig S. Feibel (Departments of Anthropology and Geological Sciences, Rutgers University, New Brunswick, USA) who examined the geology and sedimentology of the site. The samples were secured from the cleaned walls of Trenches II, III and VI (see Fig. 3 in Goren-Inbar et al. 2002b). Together the samples form a continuous series covering the larger part of the lacustrine beds. No samples were available from the upper $4.5 \mathrm{~m}$ of lacustrine sediment. Forty-two samples, listed in Table 1, were submitted for analysis.

The samples were prepared for microscopic examination according to standard procedures. After $40 \%$ hydrochloric treatment to remove carbonates (shells, snails), the samples were transferred to a bromoform-alcohol mixture (specific gravity 2.0) to separate the organic material from the mineral particles. This was followed by acetolysis, staining with safranine and transfer to silicone oil.

A major handicap in the examination of the samples was the preservation of the pollen grains. In some samples 
Table 1 Gesher Benot Ya'aqov sediment samples submitted for palynological examination; samples 15 and 16 are from the same layer and depth $(13.0 \mathrm{~m})$ in different trenches, but for practical reasons a depth of $12.9 \mathrm{~m}$ has been assigned here to sample 16

\begin{tabular}{|c|c|c|c|c|}
\hline Spectrum number & Year/sample & Trench/layer & Depth $(\mathrm{m})$ & Type of sediment \\
\hline \multicolumn{5}{|c|}{ Samples examined for pollen and included in the GBY pollen diagram } \\
\hline 25 & $96 / 201$ & VI-2 & 7.8 & Sand \\
\hline 24 & $96 / 202$ & VI-3 & 8.1 & Coquina (shell bed) \\
\hline 23 & $96 / 204$ & VI-4 & 8.4 & Black mud \\
\hline 22 & $96 / 205$ & VI-4 & 10.1 & Black mud \\
\hline 21 & $96 / 206$ & VI-5 & 10.6 & Coquina \\
\hline 20 & $96 / 207$ & VI-6 & 10.8 & Black mud \\
\hline 19 & $96 / 208$ & VI-7 & 11.2 & Black mud \\
\hline 18 & $96 / 209$ & VI-8 & 11.8 & Coquina \\
\hline 17 & $96 / 210$ & VI-9 & 12.3 & Coquina \\
\hline 16 & $96 / 211$ & VI-10 & 12.9 & Black mud \\
\hline 15 & $95 / 54$ & II-3 & 13 & Black mud \\
\hline 14 & $96 / 212$ & VI-11 & 13.4 & Molluscan sand \\
\hline 13 & $96 / 213$ & VI-12 & 14 & Black mud \\
\hline 12 & $95 / 58$ & II-7 & 16.8 & Black mud \\
\hline 11 & $95 / 61$ & II-9 & 19.9 & Fine sand and clay \\
\hline 10 & $95 / 63$ & II-11 & 21.4 & Fine sand \\
\hline 9 & $95 / 65$ & II-13 & 22.6 & Sandy clay \\
\hline 8 & $95 / 67$ & II-15 & 23.4 & Molluscan sand \\
\hline 7 & $95 / 70$ & III-1 & 24.9 & Clay \\
\hline 6 & $95 / 71$ & III-2 & 25.3 & Black mud \\
\hline 5 & $95 / 72$ & III-3 & 25.8 & Brown mud \\
\hline 4 & $95 / 75$ & III-6 & 27.4 & Grey mud \\
\hline 3 & $95 / 77$ & III-8 & 30.1 & Coquina \\
\hline 2 & $95 / 78$ & III-9 & 30.5 & Molluscan clay \\
\hline 1 & $95 / 80$ & III-11 & 31.1 & Molluscan clay \\
\hline \multicolumn{5}{|c|}{ Samples not suitable for palynological examination } \\
\hline & $95 / 53$ & II-2 & 12.7 & Molluscan sand \\
\hline & $95 / 55$ & II-4 & 13.5 & Molluscan sand \\
\hline & $95 / 56$ & II-5 & 14 & Black mud \\
\hline & $95 / 57$ & II-6 & 14.6 & Pebbly molluscan sand \\
\hline & $95 / 81$ & IV-6 & 16.4 & Molluscan sand \\
\hline & $95 / 82$ & IV-7 & 16.6 & Black mud \\
\hline & $95 / 59$ & II-8 & 18.9 & Black mud with molluscs \\
\hline & $95 / 60$ & II-9 & 19.3 & Fine sand with clay \\
\hline & $95 / 62$ & II-10 & 20.4 & Molluscan sand \\
\hline & $95 / 64$ & II-12 & 22 & Molluscan sand \\
\hline & $95 / 66$ & II-14 & 23 & Molluscan sand \\
\hline & $95 / 68$ & II-16 & 23.5 & Lignite \\
\hline & $95 / 69$ & II-17 & 23.9 & Molluscan clay \\
\hline & $95 / 73$ & III-4 & 26.2 & Black mud \\
\hline & $95 / 74$ & III-5 & 26.8 & Molluscan sand \\
\hline & $95 / 76$ & III-7 & 28.4 & Black mud \\
\hline & $95 / 79$ & III-10 & 30.8 & Clay \\
\hline
\end{tabular}


Fig. 2 Pollen diagram prepared for the sediment section at Gesher Benot Ya'aqov. Drawing A. Walanus (AGH University of Science and Technology, Cracow). For explanation, see text

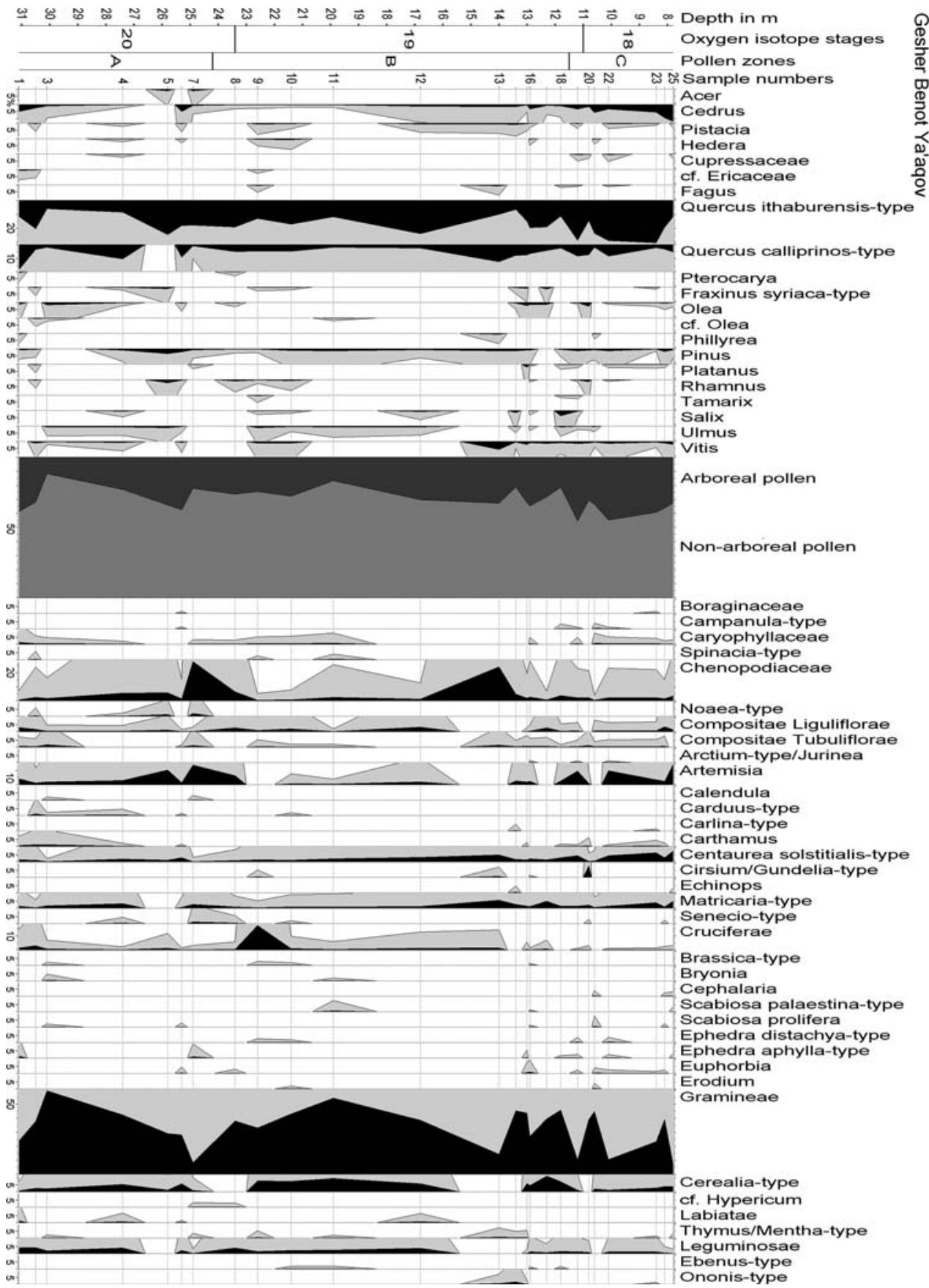

because they appeared to contain no or hardly any (identifiable) pollen grains (see Table 1).

The GBY pollen diagram (Fig. 2) was drawn by Adam Walanus (Department of Geoinformatics and Applied Computer Science, AGH University of Science and Technology, Cracow, Poland) using the POLPAL program (Walanus and Nalepka 1999). As usual three groups of plant taxa are distinguished in the diagram: (1) trees and shrubs (AP); (2) herbaceous plants (and dwarf shrubs) of the upland vegetation (NAP); and (3) water and marsh plants of the local lake-margin vegetation. 
Fig. 2 continued

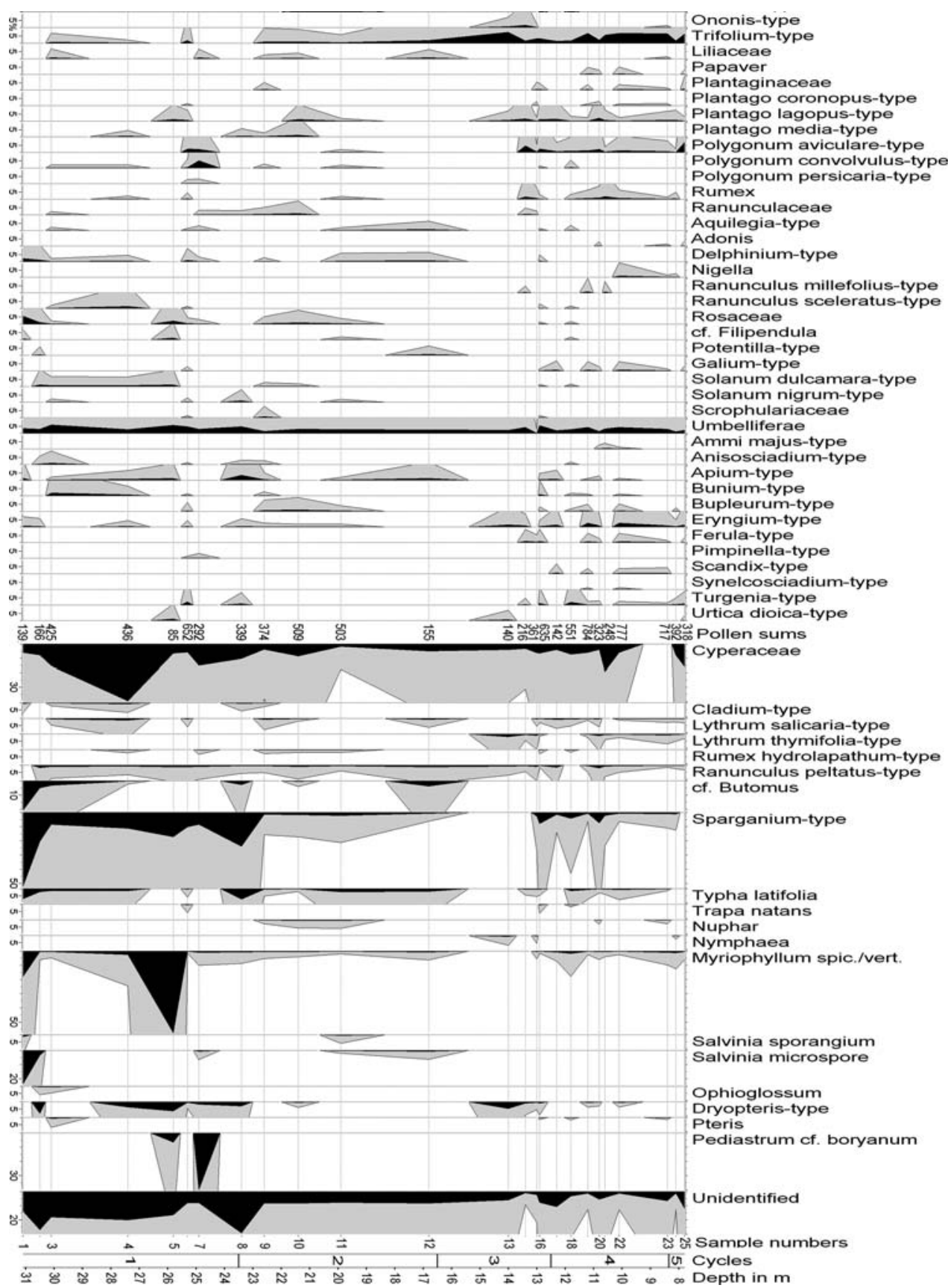

The pollen sum includes the pollen of trees and shrubs and of herbs of the upland vegetation (AP + NAP), but not of the local water and marsh plants. The proportions of the arboreal and non-arboreal upland plant taxa are expressed as percentages of the above-mentioned pollen sums. The percentages of the local marsh and water plants are calculated somewhat differently, namely on the AP + NAP sum plus the number of occurrences of the pollen type concerned in the particular sample. This is expressed in the following formula (information from A. Walanus):
Proportion(local_taxon_1) = local_taxon_1/(AP + NAP + local_taxon_1)

For instance, the Cyperaceae value of $39.9 \%$ in sample 4 is based upon a pollen sum of 725:436 AP + NAP plus 289 Cyperaceae pollen counted in this sample. Some pollen types may include upland herbs as well as marsh plants. A striking example is grass pollen (Gramineae). As will be discussed below, one may safely assume that grasses played a prominent part in the upland vegetation, but reed 
Table 2 Taxa not included in pollen diagram: present in only one sample

\begin{tabular}{|c|c|c|}
\hline & $\%$ & Spectrum \\
\hline Arceuthobium & 0.3 & 8 \\
\hline Castanea & 0.2 & 6 \\
\hline Celtis & 0.2 & 18 \\
\hline Corylus & 0.3 & 9 \\
\hline Daphne/Thymelaea & 0.3 & 9 \\
\hline Fraxinus ornus & 0.3 & 7 \\
\hline Loranthus & 0.1 & 23 \\
\hline Lonicera etrusca type & 0.2 & 11 \\
\hline Myrtus & 0.3 & 20 \\
\hline Ostrya/Carpinus orientalis & 0.3 & 7 \\
\hline Populus & 0.3 & 8 \\
\hline Punica & 0.2 & 4 \\
\hline Calligonum type & 0.2 & 18 \\
\hline Capsella type & 0.3 & 7 \\
\hline Centaurea jacea type & 0.2 & 4 \\
\hline Ceratocephalus type & 0.1 & 23 \\
\hline Cistus & 0.1 & 23 \\
\hline Dipsacaceae & 1.2 & 5 \\
\hline Filago type & 0.3 & 9 \\
\hline Gentiana & 0.2 & 10 \\
\hline cf. Gratiola & 0.6 & 12 \\
\hline Inula type & 0.3 & 20 \\
\hline Lathyrus type & 0.2 & 16 \\
\hline Matthiola type & 0.4 & 10 \\
\hline Mercurialis аппиа & 0.3 & 24 \\
\hline Plantago ovata type & 0.7 & 7 \\
\hline Primula type & 0.2 & 18 \\
\hline Pterocephalus type & 0.3 & 20 \\
\hline Rhinanthus type & 0.7 & 7 \\
\hline Sanguisorba officinalis & 0.2 & 11 \\
\hline Sideritis & 0.2 & 16 \\
\hline Teucrium type & 0.2 & 16 \\
\hline Thalictrum & 0.4 & 18 \\
\hline Theligonum & 0.4 & 10 \\
\hline Urtica pilulifera & 0.6 & 2 \\
\hline cf. Valeriana & 0.2 & 11 \\
\hline Veronica type & 0.3 & 7 \\
\hline Xanthium & 0.2 & 4 \\
\hline Anthoceros laevis type & 0.7 & 3 \\
\hline Cheilanthes & 0.5 & 9 \\
\hline Coelastrum reticulatum & 3.0 & 7 \\
\hline Pediastrum simplex & 95.6 & 7 \\
\hline Sagittaria & 0.2 & 4 \\
\hline
\end{tabular}

(Phragmites) and a few other grasses are reported from the present marsh vegetation at Hula and this may not have been very different in the past. Pollen types identified from only one sample are not presented in the diagram but are listed in Table 2. Shaded curves are $10 \times$ exaggeration.

The depth presented in the pollen diagram is measured from below the top of the upper conglomerate (see "Introduction"- "The site"). The sedimentary-sequence cycles mentioned in this section are shown at the right of the diagram. Only the bottom of cycle 5 (samples 24 and 25 ) is covered by the pollen record. No lithology column is given, but Table 1 shows the type of sediment of the samples submitted for palynological examination. The position of the oxygen isotope stages and sedimentological cycles as presented in the diagram is according to Fig. 3 in Rosenfeld et al. (2003).

The pollen diagram is subdivided into three local pollen (-assemblage) zones: GBY A, B and C. The zoning is based mainly on the Cedrus curve. In zone A (spectra 1-7) two small Cedrus maxima occur, while in zone B (spectra 8-18) Cedrus shows low to very low values. Zone C (spectra 19-25) is characterised by increasing Cedrus percentages, while Quercus ithaburensis-type also reaches its highest values in the whole diagram.

In the pollen diagram and in the text the 'old' names of plant families are used, e.g. Gramineae instead of Poaceae, Umbelliferae instead of Apiaceae and Compositae instead of Asteraceae. Nomenclature (scientific plant names) used in the present paper follows Flora Palaestina (1966-1986) and Danin (2004).

The palynological examination of the GBY samples was started by U. Baruch, at the time at the Israel Antiquities Authority, Jerusalem, and was continued by S. Bottema, Groningen Institute of Archaeology. Illness which ultimately led to his untimely death prevented S. Bottema from working up the results into a final report. At the request of R.T.J. Cappers of the Groningen Institute of Archaeology, W. van Zeist undertook the completion of the study. He did not carry out any additional laboratory work, but used the data as they are stored in the GBY pollen database. In addition, a preliminary pollen diagram and Bottema's notes on the examination were available.

\section{Results}

The environmental setting

As an introduction to the discussion of the results of the palynological examination of the GBY sediment samples, the environmental setting of the Hula Valley (geography and geology, climate, vegetation) will be briefly reviewed. Information on this subject has been taken from Horowitz (1979, 2001), Weinstein-Evron (1983), Goren-Inbar et al. (2002b), Zohary (1962) and Baruch and Bottema (1991, 1999). The narrow and elongated Hula Valley, at an 
elevation of approximately $70 \mathrm{~m}$ a.s.l., is part of the Jordan Rift Valley, and is flanked to the west by the Naftali limestone and dolomite mountains of Upper Galilee (up to 1,200 m a.s.l.) and to the east by the basaltic Golan Heights (up to 1,000 m a.s.1.). The Korazim basaltic block dams the Hula Valley at its southern end, as a result of which lakes and swamps have occupied the valley at least since early Quaternary times. The Hermon range, with a maximum altitude of ca. $2,800 \mathrm{~m}$, lies to the northeast of the valley, and the Lebanon Mts. to the northwest.

Until large-scale drainage operations were carried out in the 1950s, shallow Lake Hula, in the southern sector of the valley, had a surface area of some $14 \mathrm{~km}^{2}$, while extensive marshes bordered the lake on the north side (Fig. 1). A similar situation must have existed for hundreds of thousands of years, which, in combination with the continuous subsidence of the Hula Basin, resulted in thick lacustrine, peat and lignite deposits. At present the valley is drained to the south by the Jordan River which on its course southwards has cut its way through the basaltic Korazim Saddle to finally debouch into the Dead Sea. However, at the time of the Acheulian occupation of Gesher Benot Ya'aqov, drainage of the valley was still blocked and the lake extended further south than the Holocene lake. Thus, the GBY site was situated at the south-eastern end of palaeoLake Hula.

One may assume that there is hardly any difference between the present-day topography of the area and that of 700-800 thousand years ago. On the other hand, climatic conditions must have fluctuated in the course of the Quaternary. During glacial periods in Europe and North America, temperatures in the Near East must have dropped by several degrees to increase again during interglacial periods. Mean annual precipitation and precipitation patterns may likewise have fluctuated. The climate of the Hula region, and in the greater part of the Levant, is Mediterranean with mild, rainy winters and dry, hot summers. Annual rainfall ranges from 400 to $800 \mathrm{~mm}$ in the valley (Goren-Inbar et al. 2002b, p. 4) and from 500 to $1,000 \mathrm{~mm}$ in the mountains on both sides of the valley. Mean annual temperatures range from $16^{\circ} \mathrm{C}$ in the mountains to $21^{\circ} \mathrm{C}$ in the valley, where in the summer temperature can reach $40^{\circ} \mathrm{C}$.

The prevailing winds are westerlies, which is of importance with respect to the origin of the majority of the wind-born pollen embedded in GBY deposits. Easterly winds occur especially during the winter.

The vegetation of the greater part of the marshland adjoining the lake to the north consisted of the Cyperus papyrus-Polygonum acuminatum association. In addition to the two dominating species, various other marsh plants were found here, such as Dryopteris thelypteris, Rorippa amphibia, Galium elongatum and Lycopus europaeus. A few other marsh-plant associations formed the outer belt of the swamp (Zohary 1982a, Map 3). At the east and west sides, the lake was fringed by a marsh-vegetation belt consisting of Phragmites australis, Typha latifolia, Scirpus lacustris, Sparganium erectum (=neglectum), Lythrum salicaria, Mentha longifolia, Cyperus longus, Dittrichia (=Inula) viscosa and others. Water plants included a few Potamogeton species, Ranunculus peltatus (=aquatilis) and Nuphar lutea.

Remnants of the arboreal vegetation of the Hula Basin (beyond the lake and marshland) point to the former presence of Quercus ithaburensis-Pistacia atlantica woodland or park-forest (Zohary 1973, pp. 520-521). The same woodland vegetation is assumed to have occupied the lower reaches of the mountain slopes on either side of the valley. Herbaceous vegetation dominated by grasses and various shrubs covered the open terrain between the widely spaced trees. To the west of the valley, above $400-500 \mathrm{~m}$, the Tabor-oak woodland zone is succeeded by a belt of (originally) Pistacia atlantica-Amygdalus korschinskii woodland (Zohary 1973, pp. 167 and 374), which above $700 \mathrm{~m}$ is replaced by Quercus calliprinos-Pistacia palaestina maquis. To the east of the valley, on the west-facing slopes of the Golan Heights, at elevations above $500 \mathrm{~m}$, Tabor-oak woodland is replaced by woodland formations of evergreen Quercus calliprinos. On the highest summits of Upper Galilee and the northern Golan Heights, evergreen oak is joined by deciduous Quercus boissieri.

River-bank arboreal vegetation includes Tamarix jordanis, Populus euphratica, Platanus orientalis, Salix acmophylla, Salix alba, Ulmus minor (=canescens) and Fraxinus syriaca.

\section{Comments on arboreal pollen types}

In this section the arboreal pollen taxa (trees and shrubs) identified from GBY will be briefly discussed, including a comparison with the wood evidence of the site (Table 3). With respect to this table the following should be mentioned. The wood frequencies are taken from Table 8 in Goren-Inbar et al. (2002b). Contrary to those in the lastmentioned table, the percentages presented in Table 3 are based on the sum total of the wood occurrences exclusive of bark. In addition, some wood identifications are taken together, for instance, Quercus calliprinos and Quercus (calliprinos?). The mean pollen percentages were determined as follows. First the percentages based upon the treepollen sum $(\Sigma \mathrm{AP}$, and not $\Sigma \mathrm{AP}+\mathrm{NAP})$ were calculated. Then for each of the taxa the sum of the percentages was determined and then divided by 25 (the number of spectra). The interpretation of the GBY pollen diagram in terms of vegetation and environmental conditions of the past will be discussed below. 
Table 3 Comparison between pollen and wood percentages

\begin{tabular}{|c|c|c|c|}
\hline & $\begin{array}{l}\text { Mean } \\
\text { pollen } \%\end{array}$ & $\begin{array}{l}\text { Sample } \\
\text { frequency }\end{array}$ & $\begin{array}{l}\text { Wood } \\
\%\end{array}$ \\
\hline Acer & 0.38 & 2 & - \\
\hline $\begin{array}{l}\Sigma \text { Amygdalus/Cerasus/Crataegus/ } \\
\text { Pyrus/Rosaceae }\end{array}$ & - & - & 2.78 \\
\hline Arceuthobium & 0.04 & 1 & - \\
\hline Castanea & 0.02 & 1 & - \\
\hline Cedrus & 7.81 & 24 & 0.35 \\
\hline Celtis & 0.03 & 1 & - \\
\hline Corylus & 0.04 & 1 & - \\
\hline Cupressaceae/Juniperus & 0.21 & 5 & 0.52 \\
\hline Daphne/Thymelaea & 0.04 & 1 & - \\
\hline cf. Ericaceae (Arbutus?) & 0.2 & 3 & - \\
\hline Fagus & 0.23 & 5 & - \\
\hline Ficus carica & - & - & 0.52 \\
\hline Fraxinus (syriaca) & 0.76 & 9 & 47.48 \\
\hline Fraxinus ornus & 0.06 & 1 & - \\
\hline Hedera & 0.37 & 6 & 0.17 \\
\hline Jasminum & - & - & 0.35 \\
\hline Lonicera & 0.05 & 1 & 1.21 \\
\hline Loranthus & 0.02 & 1 & - \\
\hline cf. Lycium & - & - & 0.69 \\
\hline Myrtus (+ cf.) & 0.04 & 1 & 1.57 \\
\hline cf. Nerium & - & - & 0.17 \\
\hline Olea $(+\mathrm{cf})$. & 2.29 & 17 & 10.43 \\
\hline Ostrya/Carpinus orientalis & 0.06 & 1 & - \\
\hline cf. Periploca & - & - & 0.17 \\
\hline Phillyrea & 0.21 & 3 & - \\
\hline Pinus & 3.42 & 23 & - \\
\hline$\Sigma$ Pistacia & 0.94 & 14 & 8.35 \\
\hline Platanus & 0.6 & 9 & - \\
\hline Populus & 0.04 & 1 & 0.7 \\
\hline Pterocarya & 0.12 & 2 & - \\
\hline Punica & 0.04 & 1 & - \\
\hline Quercus calliprinos $(+\mathrm{cf})$. & 18.53 & 24 & 5.21 \\
\hline Quercus ithaburensis (+ cf.) & 56.38 & 25 & 4.87 \\
\hline Quercus sp. & - & - & 1.91 \\
\hline Rhamnus & 0.93 & 10 & - \\
\hline Rhus (+ cf.) & - & - & 0.7 \\
\hline Salix $(+$ cf. $)$ & 1.28 & 8 & 5.91 \\
\hline Tamarix & 0.14 & 3 & - \\
\hline Ulmus & 1.45 & 14 & 2.43 \\
\hline Vitis & 3.31 & 19 & 0.35 \\
\hline Ziziphus/Paliurus & - & - & 0.35 \\
\hline
\end{tabular}

For explanation, see text

In addition to the pollen and wood evidence, the present species and their distribution serve as a starting-point in evaluating the possible role of the various trees and shrubs in the vegetation of 700-800 thousand years ago. In doing so one should bear in mind that species of the remote past may not have been exactly the same as the present ones.

\section{Conifers}

Pinus. Among the arboreal taxa, Pinus (pine) is relatively well represented in the pollen record, ranking fourth after the two oak species and cedar (Table 3). However, this is insufficient to indicate that pine formed part of the vegetation in the surroundings of Pleistocene GBY. As a rule pine is seriously over-represented in the pollen rain, that is to say, its proportion in the local pollen precipitation is considerably larger than that in the vegetation of the area concerned (cf. Weinstein-Evron and Lev-Yadun 2000, p. 122). As a matter of fact, pine-pollen values of a few percent as shown in the GBY pollen diagram are usually attributed to long-distance transport. For that reason the pine pollen at GBY should not be considered evidence of the occurrence of this tree in the Hula valley and adjacent mountain slopes. This conclusion is confirmed by the wood evidence, with not a single piece of pine wood being recovered at GBY (Goren-Inbar et al. 2002b). Most probably the bulk of the pine pollen preserved in the GBY sediment section is of Pinus halepensis (Aleppo pine), at present the only native pine species of Israel and Jordan (Zohary 1973, p. 341). Pine pollen may have been blown in, particularly from north-western Israel, where Pinus halepensis could have formed forest stands on marly and chalky rendzina soils and where natural pine stands are still found (Weinstein-Evron and Lev-Yadun 2000, Fig. 1). The same reference shows that the nearest natural Aleppo-pine occurrence is on Mount Meron, some $20 \mathrm{~km}$ southwest of the GBY site. In addition, with south-easterly winds Pinus halepensis pollen may have been carried in from the Jarash/Ajlun area in Jordan (Weinstein-Evron and LevYadun 2000). Some pine pollen at GBY may have originated from Lebanon, where at present Pinus brutia is the predominant conifer (Zohary 1973, pp. 342 and 343).

Cedrus. Cedar (Cedrus libani) is not a constituent of the present-day flora of (northern) Israel; scattered cedar stands are found in Lebanon, probably relics of a formerly more widespread distribution. In almost all GBY pollen spectra cedar is represented, albeit often only in small percentages. Pollen values of $1.5 \%$ and less are certainly no proof of the presence of this tree in the area, but must be ascribed to long-distance transport. In the upper part of the diagram, Cedrus reaches values of 5\% and more, suggesting that this tree had expanded into northern Israel. The wood evidence supports this suggestion - two pieces of cedar wood were recovered from levels which correspond with the upper part of the pollen diagram (Goren-Inbar et al. 2002b, Table 9). Consequently, one may assume that during the period covered by the upper section of the pollen diagram, 
cedar was found in Upper Galilee and perhaps on Mount Hermon.

Cupressaceae/Juniperus. Juniperus is the most likely candidate for Cupressaceae pollen identified from GBY. This suggestion is supported by the wood evidence as a few wood samples have been attributed to Juniperus (GorenInbar et al. 2002b, Table 9). The nearest present-day occurrence of Juniperus (oxycedrus) is on Mount Meron mentioned above. The Mount Hermon Range, which harbours Juniperus excelsa and J. oxycedrus (Waisel 1980, pp. $54,56)$, is further away, some $40 \mathrm{~km}$ to the northeast. In the period represented by the upper part of the pollen diagram, juniper must have occurred at no great distance from the Hula Valley.

\section{Woodland and maquis}

Quercus. Deciduous Q. ithaburensis (Tabor oak) and evergreen $Q$. calliprinos are both well represented in the pollen as well as in the wood record (Table 3). One may assume that these trees played a prominent role in the vegetation in and around the Hula Valley. Within the $Q$. ithaburensis-type pollen recovered from GBY a few grains may have been of $Q$. boissieri, a deciduous oak species of the upper mountain zone of Upper Galilee (Zohary 1973, p. 359). At present $Q$. calliprinos occurs mostly as a (low) shrub; it is often the dominant species of the Mediterranean maquis. In addition, well developed trees of the species are found. The following quotation on $Q$. calliprinos as a tree is from Zohary (1973), p. 357: "when unmolested, as in cemeteries or other sites inaccessible to man and goats, it assumes a tree habit and attains a high age and considerable dimensions." Nahal (1962) describes a height of up to $15 \mathrm{~m}$ and a trunk diameter of $80-90 \mathrm{~cm}$ for $Q$. calliprinos trees in the Alaouite Mountains of north-western Syria. As at the time of the Acheulian occupation of GBY human impact on the vegetation would have been almost negligible, it may be not too farfetched to suppose that most of the $Q$. calliprinos in the Hula area was of the tree-habit type. It should be mentioned here that it is still a matter of debate as to whether shrubby and tree-shaped $Q$. calliprinos are genetically different types or whether the shrubby form is entirely the result of intensive browsing. A fair number of acorn remains were recovered from the occupation deposits (Goren-Inbar et al. 2002a, Table 1).

Pistacia. As the three Pistacia species identified from the wood remains cannot be distinguished one from the other palynologically they are taken together in Table 3. If left untouched $P$. atlantica (Atlantic terebinth) develops into an impressive tree, attaining a height of up to $20 \mathrm{~m}$ and a trunk circumference of several metres (Waisel 1980, p. 78; Zohary $1982 \mathrm{a}$, p. 41). It is assumed that before the large-scale interference of man with the vegetation, $Q$. ithaburensis $-P$. atlantica woodland ("park-forest") occupied the Hula Plain and Dan Valley (Zohary 1982a, p. 41). P. palaestina (Palestine terebinth) occurs mostly as a shrub, but if protected from coppicing and browsing it can develop into a small tree of $5-10 \mathrm{~m}$ high. The present-day $Q$. calliprinos $-P$. palaestina association of Upper Galilee is maquis with shrubby oak and terebinth as major components. It is likely that originally, with only slight human impact on the vegetation, not shrubby but tree-shaped $P$. palaestina was the predominant growth form. Judging from the wood evidence (Goren-Inbar et al. 2002b, Table 8) Palestine terebinth was scarcely or never found in the Hula area, and as a consequence the contribution of this species to the pollen precipitation at GBY must have been negligible. The identification of some wood specimens as $P$. vera is puzzling. Did this species, which is native to Iran, really grow here in Early/Middle Pleistocene time, only to disappear later on? (See also Goren-Inbar et al. 2002b, p. 108).

The wood record suggests that Pistacia was almost as common as Quercus (Table 3). The pollen evidence, on the other hand, provides a completely different picture, namely that Pistacia would have played a far less important role in the vegetation of the Hula area than Quercus. One wonders whether this discrepancy between the wood and pollen records has to be ascribed to an under-representation of Pistacia (atlantica) in the pollen record. Surface-sample evidence from western Iran (study of modern pollen rain) points to a serious under-representation of $P$. atlantica in the pollen record as compared with Quercus (van Zeist and Bottema 1977, p. 74).

Olea. Olive is surprisingly well represented in both the pollen and wood records (Table 3 ). It is beyond doubt that the wild olive, O. europaea, var. oleaster, is concerned here. In the East-Mediterranean territory, wild olive is confined to the lower zone of evergreen maquis (Zohary 1973 , p. 372). In view of the conspicuously good representation of olive at GBY, one wonders whether at the time it was a common constituent of the oak-terebinth woodland of the Hula Plain and the lower reaches of the adjoining mountain slopes (see above).

Acer (maple) is scarce in the GBY pollen record, being only identified in two samples (spectra 5 and 7). Although no Acer wood was identified in GBY (Table 3), nevertheless one should not exclude the possibility that at the time this tree was present in northern Israel. Two arguments in support of this suggestion can be adduced: A. obtusifolium ssp. syriacum is reported from Upper Galilee (Flora Palaestina II, p. 302), and secondly insect-pollinated Acer is very seriously under-represented in the pollen rain, as has been demonstrated for A. cinerascens in western Iran (cf. van Zeist and Bottema 1977, p. 74). It is likely that Acer 
played a minor role in the Early/Middle Pleistocene vegetation of northern Israel.

Hedera. Six occurrences of Hedera (ivy) pollen suggest that this climbing shrub was not rare in the Hula area. In this connection it should be mentioned that experience from Europe has shown that Hedera has a poor pollen dispersal (see also Bottema 2001). Most probably H. helix, which still occurs in Israel as a very rare species (Flora Palaestina II, p. 378), is concerned here, and would have been found in the $Q$. ithaburensis-P. atlantica woodland of the Hula Plain.

Rosaceous trees and shrubs, such as Amygdalus and Pyrus (see Table 3), are usually seriously under-represented in the pollen record and, moreover, may be difficult to identify as such if the preservation is poor. For that reason the absence of pollen of arboreal Rosaceae, in contrast to their fairly good representation in the wood record, should not be surprising.

Ericaceae. One wonders whether the pollen type identified as cf. Ericaceae could have been from Arbutus andrachne (strawberry tree), the only ericaceous species of the indigenous flora of Israel (Flora Palaestina III, p. 1). This small tree occurs primarily as an associate of $Q$. calliprinos maquis, but originally it must have been a constituent of Mediterranean woodland vegetation.

Daphne/Thymelaea. The species identity of this pollen type is uncertain. Thymelaea hirsuta has a wide distribution in Israel (Flora Palaestina II, pp. 330-331), but is absent from the Hula Plain (Danin 2004, p. 209). Daphne is not recorded from the Hula Valley or adjacent regions.

Two semi-parasitic arboreal taxa are represented by one pollen grain each. Arceuthobium is not mentioned from Israel in the Flora Palaestina, but it is feasible that $A$. oxycedri, a parasite on Juniperus, occurred here in Early/ Middle Pleistocene time. Because of its poor pollen dispersal, long-distance transport may be ruled out. Plicosepalus (=Loranthus) acaciae, a parasite on Acacia, Ziziphus, Tamarix and a few other shrubs, is reported from as far north as the southern Jordan Valley and Beit Shean Valley, but not from the northern Jordan Valley (Flora Palaestina I, p. 46; Danin 2004, p. 26). Past conditions in the Hula Valley, in particular higher temperatures, may have been more suitable for Plicosepalus. Here, too, longdistance transport is highly unlikely.

Rhamnaceae. Evidence of Rhamnaceae at GBY poses a problem in that the pollen is attributed to Rhamnus, whereas two wood samples are identified as Ziziphus/ Paliurus (Goren-Inbar et al. 2002b, p. 46). At present, Ziziphus spina-christi and Z. lotus are very common in the Upper Jordan Valley (Zohary 1982b, p. 155), while on the east side the Hula Valley is bordered by the Ziziphetum spinae-christi association (Zohary 1982a, Map 3). For that reason one wonders whether the pollen attributed to
Rhamnus could have been of Ziziphus. The two pollen types show a great resemblance to each other. On the other hand, as Rhamnus is reported from north-eastern Israel (Flora Palaestina II, pp. 35, 36), its occurrence in the Hula area in Early/Middle Pleistocene time should not be ruled out.

Fagus presents another kind of problem. Might six pollen grains dispersed over five samples $(20 \%$ of the GBY pollen spectra) be considered evidence of the former presence of beech in northern Israel? The nearest present-day occurrences of $F$. orientalis are in the Amanus Mountains, Hatay district, south-central Turkey (Davis 1965-2000, vol. VII, Map 77), some $400 \mathrm{~km}$ north of the Hula Basin. With respect to the possibility of long-distance transport, it should be mentioned that only one Fagus pollen grain was counted in 139 samples of the Hula pollen diagram prepared by U. Baruch and S. Bottema, covering the final stages of the last glacial and the Holocene. (So far only a concise version of the diagram has been published: Baruch and Bottema 1999). It must be left undecided whether at the time Fagus formed part of the indigenous flora of northern Israel, or whether the GBY beech pollen should be classified among the exotic pollen types described under that heading below.

\section{Riverine arboreal vegetation}

This category of trees and shrubs, which inhabit banks of permanent and intermittent water flows, is well represented in both the pollen and wood records. No hydrophytic trees and shrubs are reported from the shores of historical Lake Hula, but one wonders whether this could have been different in other periods.

Fraxinus. A conspicuous discrepancy between the pollen and wood records as has been determined for Pinus can easily be explained (see above). On the other hand, it is much more difficult, if not impossible, to give a satisfactory explanation for the discrepancy between the wood and pollen proportions of $F$. syriaca. Almost half of the wood specimens recovered from GBY are of Fraxinus (47.48\%), whereas the mean pollen value is less than $1 \%(0.82 \%)$. One may assume that ash occurred as a constituent of riverine (lake- and river-bank) vegetation (the upland is too dry for this species), and Fraxinus driftwood and pollen must have originated from the same source. Following the model of the palaeo-drainage pattern of the area as presented in Goren-Inbar et al. (2002b, Fig. 23), this source should almost exclusively have been the bank vegetation of Nahal Rosh Pinna, at present a tributary of the Jordan River. Fraxinus is a wind-pollinated species with a moderately good production and dispersal of pollen. Most ash pollen may have reached the site through the air, but some 
may have been carried in by the water, in the same way as the wood.

There remains the question of the comparatively poor representation of Fraxinus in the pollen record. One factor to be taken into account in this connection is the preservation. As has been discussed above, conditions for the preservation of pollen were not ideal in the GBY deposits, which could have affected the fairly fragile Fraxinus pollen more seriously than, for instance, the more sturdy Quercus pollen.

Salix. In contrast to Fraxinus, Salix is not only well represented in the wood record, but shows also a fairly high mean pollen value (Table 3 ). The latter may seem somewhat curious because willows are insect-pollinated. However, the stamens densely clustered on male catkins are freely exposed to the air, and for that reason a fair proportion of willow pollen may be carried away by the wind. At present, S. alba and S. acmophylla occur in the Upper Jordan Valley (Zohary 1962, p. 167), but the pollen does not permit us to determine which willow species were found here at the time.

Ulmus (elm), too, is fairly well represented by pollen as well as wood remains, suggesting that at the time this tree was much more common in the Hula area than nowadays. Both Zohary (1982a, p. 52) and Waisel (1980, p. 120) specifically mention that $U$. minor (=canescens) occurs only scarcely in (northern) Israel. Zohary (1982b, p. 128) wonders whether this elm species is a relic of a rainier period.

Vitis. Although only two wood specimens of Vitis (vinifera) were recovered, the relatively high mean pollen value and the high sample frequency (Table 3) suggest that wild grape vine was by no means a rare species in the Hula area. It is assumed here that grape vine was a constituent of the riverine vegetation. In contrast to cultivated grape vine, the wild form appears to have a fairly good pollen dispersal.

\section{Other riverine trees and shrubs}

It is somewhat surprising that no wood remains were identified from Platanus (orientalis), a characteristic tree of the banks of perennial streams, although its pollen was counted in several samples. Could it be that the plane tree did not occur in the vicinity of the GBY site at the time and that the pollen of this wind-pollinated tree was carried in from more northerly or southerly sections of the Jordan Valley?

Also no macro-remains of Tamarix were recovered, only a few pollen grains which do not tell us much about the role of tamarisk in the streamside vegetation of the Hula Valley. Fig. 59 in Zohary (1962) shows dense T. jordanis shrub vegetation on the banks of the Jordan River in the Lower Jordan Valley, but this picture does probably not apply to the Upper Jordan Valley in Early/Middle Pleistocene times.
Evidence of Populus (euphratica) consists of one pollen grain and one wood specimen (Table 3 ). One pollen grain does not say much; experience has shown that in spite of being a wind-pollinated tree, poplar pollen is only rarely preserved in lake and marsh deposits. The single wood sample indicates that poplar was rare in the area from which most of the wood remains at GBY must have originated (Nahal Rosh Pinna catchment area).

It is likely that wild fig (Ficus carica), represented by a few wood remains, occurred as a streamside tree.

Punica. The single Punica (granatum) pollen grain is puzzling in that at present wild pomegranate does not occur in the southern Levant (Zohary and Hopf 2000, p. 171). The species is a common constituent of the humid southCaspian and northeast Turkish forest belts. One wonders whether in the remote past, Punica could have maintained itself in riverine habitats in the Upper Jordan Valley (and other places).

\section{Exotic tree-pollen types}

It is assumed of a small number of trees represented in the pollen record and listed below that they were not found in northern Israel and/or adjacent regions at the time of the Acheulian occupation of the GBY site. We are dealing here with wind-pollinated species which do not form part of the indigenous flora of Israel. Celtis australis is planted in Israel (Flora Palaestina I, p. 36), and probably the same applies to Celtis reported from North Lebanon (Post and Dinsmore 1932, vol. II, p. 516). The nearest occurrences of the species in question are from 150 to over $400 \mathrm{~km}$ from the Hula Valley. Of these, two Pterocarya pollen grains were counted, of the others only one. Pollen transport through the air over hundreds of kilometres is a well-known phenomenon and could explain the presence of the pollen types listed below in the lake deposits:
Carpinus orientalis

Ostrya carpinifolia

Fraxinus ornus

Corylus

avellana

Celtis australis vol. II, p. 516): indigenous?? Southcentral Turkey (Davis 1965-2000, vol. VII, p. 650) 
Castanea E of Antalya, SW Turkey (Davis 1965-

sativa

Pterocarya

fraxinifolia

2000, vol. VII, Map 78)

South-central Turkey (Davis 1965-2000, vol. VII, Map 75).

Some notes on herbaceous pollen types

Each of the arboreal pollen types identified from the GBY site and discussed in the previous section is assumed to include only one or a limited number of species presently found in northern Israel and adjacent areas. As for the herbaceous pollen types, it is often more complicated. Not only may the genera to which level herb pollen is usually identified include a great number of species, but particular pollen types may even embrace several genera. In addition, identification may sometimes not be possible beyond the family level; striking examples are Gramineae and Cyperaceae. It is evident that the more species and genera are included in a particular pollen type, the less informative the type concerned can be on past vegetation and environmental conditions. Only a limited number of non-arboreal pollen types will briefly be reviewed below.

Chenopodiaceae. Three types of chenopod pollen are distinguished in the present study. These are Noaea-type, Spinacia-type and unidentified Chenopodiaceae, the latter also indicated in other publications as Atriplex-type. Unfortunately, the pollen grains of a large number of Chenopodiaceae species cannot be distinguished one from the other. Noaea mucronata is a characteristic species of steppe vegetation, but the Noaea pollen type includes at least three other chenopod genera, namely Cornulaca, Girgensohnia and Seitlitzia (van Zeist and Bottema 1977, p. 33). By far the majority of the Near Eastern Chenopodiaceae are halophytic species, characteristic of more or less saline soils. In addition, chenopods of non-saline soil occur, for example various Atriplex and Chenopodium species, which at present are mostly confined to man-made habitats but which originally must have formed part of the natural vegetation.

Gramineae (Poaceae). As is evident from the pollen diagram, grasses must have played a prominent role in the herbaceous vegetation of the Hula area. Unfortunately, the pollen gives almost no information on the genera, let alone species, of grasses involved. The only grass-pollen type identified is Cerealia-type which is distinguished from other grass pollen by its size (at least $40 \mu$ in silicone-oil mounted slides), its thick wall and pronounced annulus. At Hula, Cerealia-type pollen may include that of wild cereals, such as wild emmer wheat and wild barley (the progenitors of cultivated wheat and barley), but some other Near Eastern grasses also have Cerealia-type pollen, for example species of Aegilops. The grass pollen at GBY must partly have originated from the local marsh vegetation. Phragmites australis, Arundo donax and Saccharum ravennae are mentioned from the Hula swamp by Zohary (1982a, p. 144). In addition, grasses should have been common constituents of the field layer (herb and dwarf-shrub undergrowth) of the Tabor oak woodland. However, we are in the dark about the (fluctuating) proportions of grass pollen originating from the marshland on the one hand and the upland vegetation on the other.

Cyperaceae. One may safely assume that almost all Cyperaceae pollen at GBY is of marsh-plant species. Only a few pollen grains may have originated from Carex species in the upland vegetation. Of the Cyperaceae pollen, only Cladium-type has been distinguished as a separate type. C. mariscus is one of the marsh plants reported from the Hula swamp as a common species (Danin 2004, p. 463). The most characteristic and dominant species of the former Hula marshes was Cyperus papyrus. In addition to some other Cyperus species, Scirpus and Carex were represented by several species (Zohary 1982a, p. 144; see also Flora Palaestina IV, pp. 346-375).

Umbelliferae (Apiaceae). In contrast to the families discussed above, Umbelliferae are insect-pollinated implying that, as a rule, they should be less well represented in the pollen precipitation than wind-pollinated species. Nevertheless, Umbelliferae are reasonably well represented at GBY. A notably large number of different pollen types has been distinguished (Ammi majus-type to Turgenia-type in the pollen diagram), but a large proportion of the pollen grains could not be attributed to a particular type, partly because of poor preservation (unidentified Umbelliferae). Unfortunately, we are in the dark about the species that were found in the Hula area. The eponymous genera often not only include species of divergent ecological behaviour, but the Umbelliferous pollen types identified may also comprise several genera (cf. van Zeist and Bottema 1977, pp. 42, 55). However, it is evident that the many different pollen types at least point to a considerable diversity of species. Umbelliferae are common constituents of steppe and steppe-like vegetation in the Near East. At GBY, they must have been components of the herb and dwarf-shrub field layer of the woodland of valley floor and flanking mountain slopes. In periods of arid climatic conditions, steppe may have approached the valley. A few Umbelliferous species could have formed part of the marsh vegetation. For example Apium graveolens and A. nodiflorum are described from wet habitats (Zohary 1982a, p. 143; Flora Palaestina II, p. 416).

Compositae (Asteraceae). Among the Compositae Liguliflorae from GBY no particular pollen types have been distinguished, but various types could be determined in the pollen of Compositae Tubuliflorae, shown as Arctium-type 
to Senecio-type in the pollen diagram. Compositae are usually insect-pollinated, but Artemisia is wind-pollinated. One may assume that at GBY it represents Artemisia sieberi (=herba-alba), "one of the most common plants in the steppes and semi-deserts of the area", that is to say, the Near East (Zohary 1973, p. 392). Strictly speaking, A. sieberi (=herba-alba) should be classified as arboreal pollen because it is a low shrub (dwarf shrub) and not a herb. However, in palynological practice this typical steppe plant is placed among the non-arboreal species. As a matter of fact, more species of steppe and desert-steppe are perennial dwarf shrubs. Among the other Tubuliflorae pollen types, Centaurea solstitialis-type and Matricaria-type are comparatively well represented. The $C$. solstitialis pollen type comprises a great number of Centaurea species (cf. van Zeist and Bottema 1977, pp. 34-35; Bottema and Woldring 1984, pp. 128-129), predominantly species of open herbaceous and dwarf-shrub vegetation, and at present also of cultivated and disturbed ground (cf. Danin 2004, pp. 361364). Various species of Achillea and Anthemis included in the Matricaria pollen type are reported from steppe vegetation.

Cruciferae (Brassicaceae). A few pollen grains of this family have been attributed to separate types-Brassicatype, Capsella-type, Matthiola-type. Cruciferae are insectpollinated and occur as constituents of open plant communities. With one exception (almost 20\% in spectrum 9), pollen values are low, but it is this exception that draws the attention. Such a high percentage of an insect-pollinated taxon suggests that the species concerned was common in the very local vegetation, which in this case should have been the local marsh vegetation. One may think here of Nasturtium officinale and Rorippa amphibia which are both mentioned from swampy places (Flora Palaestina I, pp. 277-278).

Plantago. Three Plantago-pollen types have been distinguished of which $P$. lagopus-type is best represented in the GBY pollen record. A fair number of Plantago species are reported from open vegetation (desert-steppe, steppe, dwarf-shrub land) in Israel (Flora Palaestina III, pp. 220232), but there is no information as to which species are included in the pollen types distinguished. Various plantain species, including $P$. lagopus, have adapted themselves to the conditions of man-made habitats, such as fallow fields. The modest pollen percentages suggest that wind-pollinated Plantago played a subordinate role in the past vegetation.

Ephedra. The eponymous species E. distachya is not reported from Israel, but E. foeminea (=campylopoda) and E. aphylla (=alte) are found throughout the country, in (open) dwarf-shrub vegetation (Flora Palaestina I, pp. 2223; Danin 2004, p. 21). One may assume that the Ephedra pollen embedded in the GBY sediment section came from the surrounding area. The low and discontinuous pollen curves suggest that wind-pollinated Ephedra played only a minor role in the Early/Middle Pleistocene vegetation.

Ranunculus. $R$. peltatus-type, which represents floating and submerged water-crowfoot species (subgenus Batrachium), is placed among the water- and marsh-plant taxa on the right-hand side of the pollen diagram. In principle, $R$. sceleratus-type should also have been shown there, because this species is mentioned from swamps (Flora Palaestina I, p. 208). R. millefolius, on the other hand, is a dry-land species of steppe and open dwarf-shrub vegetation (batha) according to Flora Palaestina (I, p. 203).

Polygonum. None of the three eponymous Polygonum species is reported from Israel (Flora Palaestina I, pp. 5158). One wonders whether $P$. equisetiforme and/or $P$. arenastrum, at present common species of waste places, could be represented by the $P$. aviculare or $P$. convolvulus pollen type. Persicaria acuminata (=Polygonum acuminatum) and Persicaria senegalensis (=Polygonum senegalense), both mentioned from the Hula swamps, have pollen of the Polygonum persicaria type, which was identified from only two samples.

Lythrum. As for the two Lythrum pollen types, L. salicaria is (was) a constituent of the Hula swamp vegetation, but L. thymifolium is a rare species in Israel and the Golan and is not mentioned from the Hula Plain. It is likely that the L. thymifolium-type pollen is of another species, e.g. $L$. hyssopifolium or L. junceum, both marsh plants recorded from the Hula Valley (Flora Palaestina II, pp. 368-371; Danin 2004, p. 218).

In contrast to the great number of nut remains of Trapa natans (water chestnut) recovered from GBY (Goren-Inbar et al. 2002a, Table 1), pollen evidence is fairly meagre, represented in three samples by nine pollen grains in total. Nevertheless at least Trapa pollen was identified. This does not apply to Euryale ferox, the other water plant of which many seeds were secured (Goren-Inbar et al. 2002a, Table 1). No pollen of this species was found or recognized as such. Two other members of the Nymphaeaceae Family, namely Nuphar and Nymphaea, are represented by pollen as well as macro-remains (Melamed 2004). At present, Trapa and Euryale do not occur in Israel and the same holds for Salvinia.

Macro-remains of three Potamogeton species are reported by Melamed (2004), but no pondweed pollen has been identified; conditions at GBY may have been unfavourable for the preservation of this fragile pollen type. This certainly holds for the delicate pollen of Najas and Ceratophyllum, both represented by macro-remains (Melamed 2004). On the other hand, pollen as well as macro-remains of Sagittaria and Myriophyllum were recovered, albeit with only one Sagittaria pollen grain being found. 
Table 4 Pollen percentages of samples from the Benot Ya'aqov Formation, Emek Hula 1 Borehole (after Horowitz 1979, p 220)

\begin{tabular}{|c|c|c|c|c|c|}
\hline Depth (m) & 155 & 162 & 212 & 250 & 280 \\
\hline Quercus & 34 & 28 & 21 & 6 & 22 \\
\hline Pistacia & - & 0.5 & - & 0.5 & 2 \\
\hline Olea & 4 & 2 & 4 & 2 & 13 \\
\hline Pinus & - & 0.5 & - & - & - \\
\hline Cedrus & - & 1 & - & - & - \\
\hline Fagus & - & 2 & 0.5 & - & 1 \\
\hline Celtis & - & - & 0.5 & - & - \\
\hline Acer & - & - & - & 0.5 & - \\
\hline Ceratonia & 1 & - & - & - & - \\
\hline Sum AP & 39 & 34 & 26 & 9 & 38 \\
\hline Gramineae & 29 & 19 & 35 & 16 & 35 \\
\hline Artemisia & 4 & 6 & 2 & 24 & 9 \\
\hline Chenopodiaceae & 8 & 10 & 3 & 23 & 7 \\
\hline Compositae & - & 1 & 6 & 8 & 2 \\
\hline Centaurea & - & - & 1 & 1 & - \\
\hline Umbelliferae & 5 & 10 & 5 & 3 & 4 \\
\hline Cruciferae & - & 3 & 4 & 0.5 & 0.5 \\
\hline Plantago & 1 & - & 1 & - & - \\
\hline Ephedra & 1 & - & - & 2 & - \\
\hline Cyperaceae & 9 & 11 & 9 & 6 & 12 \\
\hline Other herbs & 1 & 4 & 4 & 1 & 0.5 \\
\hline Sum NAP & 58 & 64 & 70 & 85 & 60 \\
\hline Bank vegetation & 3 & 2 & 1 & 4 & 3 \\
\hline Water plants & 1 & 0.5 & 4 & - & 1 \\
\hline Pollen counted & 80 & 218 & 207 & 216 & 199 \\
\hline
\end{tabular}

$A P$ arboreal, NAP non arboreal pollen

\section{Discussion}

\section{Upland vegetation}

On the basis of a span of time of some 100,000 years for the deposition of $34.3 \mathrm{~m}$ of sediment, the pollen diagram comprising $23.3 \mathrm{~m}$ of lacustrine beds should represent a period of $65,000-70,000$ years. The interpretation of the pollen evidence in terms of the vegetation at the time of the early hominid occupation and of possible changes therein over the course of time is handicapped by two factors. As mentioned above ("Materials and methods"), the poor preservation of various samples must have affected the quality of the pollen counts. In addition, distances in depth between successive samples can be quite large, up to $3.1 \mathrm{~m}$ (between samples 11 and 12), implying that there are hiatuses of some 3,000-9,000 years in the pollen record. Of course, other diagram sections are better covered. Nevertheless, in spite of these handicaps the pollen diagram is thought to provide a fair picture of the past vegetation. Besides, as this diagram is all we have, there remains no other choice than to explore to what degree of detail interpretation is justified. Moreover, how far the palynological results comply with those of other ecological studies applied to the GBY site should be assessed.

In connection with the GBY pollen record it should be mentioned that Horowitz (1979, pp. 217 and 220) has analysed a few samples from the Benot Ya'aqov Formation. One of these was recovered from the outcrop at GBY and five from a borehole in Lake Hula. The results from the latter are presented in Table 4. As the sediment section excavated at Gesher Benot Ya'aqov probably covers only part of the Benot Ya'aqov Formation in the lake sediment, we do not know which spectra of Table 4 correspond with the GBY pollen diagram. With the exception of the spectrum at $250 \mathrm{~m}$, the other spectra of Table 4, with arboreal pollen values of 26-39\% and predominantly Quercus, would fit into the GBY diagram, taking into account that the Table 4 spectra are less detailed as to numbers of pollen types distinguished.

As has already been noted by other researchers, the Quaternary vegetation of the southern Levant, and consequently of north-eastern Israel with the Upper Jordan Valley, did not undergo drastic changes as a result of the alternation of glacial and interglacial periods. It looks as though most of the species could maintain themselves in the area throughout the Quaternary. The effects of changes in climate on the vegetation would particularly have been of a quantitative nature in the form of the successive increase and decrease of arboreal vegetation and the corresponding contraction and spread of steppe-like vegetation (dwarf shrubs, herbs). Of particular interest for the interpretation of the GBY pollen record is the Hula pollen diagram prepared by Weinstein-Evron (1983) for a sediment core covering the greater part of the last glacial period (the Würmian or Weichselian glaciation in Europe). This Hula diagram gives a much more detailed picture than the GBY diagram. In Weinstein's Hula core about the same length of time as at GBY is covered by almost eight times as many spectra.

Together with the wood evidence (Goren-Inbar et al. $2002 b)$ the pollen record suggests that the arboreal vegetation in the surroundings of the GBY site was comparable with the inferred present-day natural tree cover. Quercus ithaburensis-Pistacia atlantica woodland is thought to have occupied the Hula Valley and the lower reaches of the surrounding mountain slopes. The assumed prominent role of $P$. atlantica is seemingly in contradiction with the low Pistacia-pollen values, but as has already been discussed, this tree is seriously under-represented in the pollen precipitation. Moreover, the wood evidence clearly indicates that $P$. atlantica was a common tree in the area. At higher elevations deciduous Tabor oak would have given way to evergreen Quercus calliprinos and higher still, P. atlantica 
would have disappeared. Fraxinus, Ulmus, Salix and Vitis are thought to have found suitable habitats along watercourses, which for the vicinity of the GBY site would primarily have been the Nahal Rosh Pinna, in addition to a few other streams (see Goren-Inbar et al. 2002b, Fig. 22). Salix also probably occurred by the lake. The role of Platanus, Populus and Tamarix as streamside trees and shrubs is less clear.

Although represented in the pollen record, Pinus (halepensis) is unlikely to have occurred in north-eastern Israel, but Cedrus (libani) is assumed to have reached the area during the final stages of the pollen diagram. With respect to cedar, the following should be mentioned. The two small Cedrus peaks in pollen zone A may not yet be considered evidence of the occurrence of this conifer in northern Israel, but at least cedar was approaching the area. The temporary expansion of cedar is thought to indicate periods of increased humidity, occasioned by either increased precipitation or a lowering of the temperature. Similarly, the rise of the cedar curve in zone $\mathrm{C}$ should point to an increase in humidity. The expansion of Quercus ithaburensis, as suggested by the pollen record of zone C, would likewise be in conformity with increased humidity levels. However, as will be discussed below, WeinsteinEvron (1983) suggests an alternative explanation. It is not clear whether the increase of Cedrus pollen values marks the arrival of cedar in the surroundings of the Hula Valley, or whether only the two uppermost spectra are fair evidence of the presence of this tree in the area. It is striking that the final increase of Cedrus (spectra 24 and 25) is accompanied by a marked decline in Quercus ithaburensis-type. A similar behaviour of the two curves is also observed in Weinstein's Hula diagram - the conspicuously high Cedrus values in zone 9 of her Hula diagram coincide with markedly lower Quercus frequencies. Thus, it looks as though oak retreated when cedar had reached the area.

The high non-arboreal pollen values suggest that tree growth must have been fairly open, implying that during zone A and zone B time woodland (and not forest) must have prevailed, and locally perhaps steppe-forest, that is steppe with scattered tree stands. As for the nature of the steppe-like field layer, attention is drawn to the usually high Gramineae frequencies and, except for a few maxima, (relatively) low values of Chenopodiaceae and Artemisia. As has already been mentioned above, part of the grass pollen could have been of reed (Phragmites) and a few other grasses of the Hula marsh vegetation, but the majority of the grass pollen, including Cerealia-type, was most likely of grasses of the upland vegetation. High pollen values of Artemisia and Chenopodiaceae are indicative of wormwood-chenopod-dominated dwarf-shrub steppe, whereas grasses are the predominant constituents of more humid steppe. The GBY diagram registers indications of two drier periods, in the form of two Chenopodiaceae maxima. It is striking that these maxima coincide with minima in the grass-pollen curve, suggesting that the humid steppe had temporarily been replaced by a drier type of steppe. The term 'temporarily' should not be taken here too literally, because periods of many thousands of years may have been involved. For the section between spectra 5 and 8 the inference of a drier period is supported by increased Artemisia values. The two curves (Artemisia and Chenopodiaceae) show here a similar course. Surprisingly this dry period seems to have been interrupted by a moister interval in which cedar expanded to some extent. The upper chenopod maximum (spectrum 13) is not accompanied by a similar Artemisia peak. On the contrary, Artemisia was not identified at all from the sample concerned. The fair, albeit not continuous representation of the steppe plant Artemisia in the upper section of the diagram seemingly contradicts the hypothesis of increased humidity as the forcing factor of the expansion of cedar. With reference to Zohary (1973, pp. 345-346), Weinstein-Evron (1983) suggests that a decrease in temperature in association with more continental conditions had led to the spread of cedar towards lower elevations. The hypothesis of increased continentality could explain why at the same time as cedar, Artemisia had expanded to some extent. The Gramineae and Artemisia curves in zone $\mathrm{C}$ show an opposite behaviour in that maxima in one curve coincide with minima in the other. One wonders whether the alternating proportions of wormwood and grasses in the vegetation were the expression of fluctuations in continentality or humidity.

The herb and dwarf-shrub vegetation of the GBY area must have been rich in species as is suggested by the great number of non-arboreal pollen types identified from the site. However, as has already been emphasized, we are usually in the dark about the species identity of the pollen types concerned. Gramineae, Umbelliferae and Compositae must have played a prominent part in the upland vegetation throughout the period covered by the pollen record, but it is not possible to be more specific about the composition of the steppe-like vegetation, let alone about vegetation patterns in relation to edaphic conditions.

It is beyond doubt that the vegetation as inferred from the pollen record could have sustained at least modest numbers of large herbivores, such as elephants, rhinos and aurochs (cf. Goren-Inbar et al. 2002b, p. 2). The carrying capacity of the vegetation in the wide surroundings of the Hula Valley was certainly not less than that of the savannas and parklands of East Africa, well known for its abundant wildlife. The Hula lake and marshes must have offered ideal conditions for hippos. Of prime importance for the subsistence of the early hominids was the rich herbaceous 
and dwarf-shrub field layer which served as food for fallow deer, gazelle, red deer and other animals.

The question has been raised as to what extent animals and early man may have influenced the vegetation. Indications of human control of fire at GBY (Goren-Inbar et al 2004) have given occasion to speculations on intentional burning of the vegetation, either for hunting purposes or for improving forage for game animals ("environmental management"). The pollen evidence does not provide any clue in this respect. However, it is hard to believe that the fairly open character of the vegetation suggested in the present paper was due to human and/or animal disturbance rather than to climatic factors.

Lake and marsh vegetation

The local lake and marsh vegetation, as inferred from the pollen record, is discussed here in relation to the cyclicity of the GBY sedimentary sequence. As mentioned above ("Introduction"_-"The site"), five sedimentary cycles shown on the right hand side of the diagram are distinguished. Each of the cycles is thought to represent a succession of lower lake-levels in the early stages to higher levels in the later stages (Rosenfeld et al. 2003. The high Salvinia-spore percentage in the lowermost sample points to open water. Salvinia is a small, floating fern of warm regions. From the same sample two sporangia of Salvinia and pollen of the water plant Myriophyllum were identified. In addition, several marsh plants are represented in spectrum 1, among which were Typha latifolia, Sparganium erectum (=neglectum) and/or Typha angustifolia (Sparganium-type pollen) and (cf.) Butomus umbellatus. In the succeeding spectrum 2 evidence of open water is strongly reduced and Ranunculus peltatus-type (Batrachium-type) appears. The fact that this pollen type is represented throughout almost the whole diagram makes one wonder whether it indicates here a species that is found in (shallow) open water as well as on swampy soil (perhaps different species?). The marsh plant Ranunculus sceleratus is represented in spectra 3 and 4 . It looks as though open water had retreated to some extent, and the peak of Cyperaceae in spectrum 4 suggests that Cyperus papyrus swamp had reached or at least had approached the area of the GBY site.

The marsh-plant phase was succeeded by more open water with Myriophyllum (spectrum 5), Salvinia (spectrum 7) and Pediastrum cf. boryanum, a green alga (spectra 5 and 7). In addition to Pediastrum cf. boryanum, $P$. simplex (Table 2) is represented in sample 7 by a very large number of specimens. A few pollen grains of Trapa natans were identified from sample 6. Dryopteris-type (probably Thelypteris palustris), Cyperaceae, Ranunculus peltatus-type and Lythrum represent the marsh-vegetation belt along the lake. Except for the bottom with evidence of open water, the pollen record of cycle 1 is in agreement with the conclusion based upon the sedimentary sequence that low(er) lake levels during the first stages of the cycle were succeeded by high(er) levels in the later stages.

A similar succession from lower to higher lake levels could possibly be inferred also from the cycle 2 pollen record. In addition to the marsh plants mentioned above for cycle 1 , attention is drawn to the comparatively high value of Apium-type pollen in spectrum 8, which pollen type includes Apium graveolens and A. nodiflorum. It has already been suggested that the Brassica-type peak in spectrum 9 could have been of marsh plants such as Rorippa amphibia and Nasturtium officinale. Evidence of water plants is scarce and, moreover, Nuphar is already represented in the lower section of the cycle (spectra 9 and 10). One Salvinia micro-spore in each of samples 11 and 12 and a few Salvinia sporangia in sample 11 should provide evidence of open water, and consequently of increased lake level, during the second part of cycle 2. Admittedly, the evidence is very meagre, but the pollen records of cycles 3 and 4 do not permit any suggestion of changes in water level at all.

The results of the diatom and ostracod studies of the GBY sediment section (Rosenfeld et al. 2003) cannot easily be brought into line with those of the palynological examination. The diatom and ostracod distributions point to a gradual shift to (slightly) more saline conditions from the level of pollen sample 12 upwards. However, an increase in lake-water salinity does not find expression in the pollen evidence. The geochemical data obtained from ostracod shells are thought to reflect a cooler period for the interval corresponding with pollen samples $8-12$, followed by a gradual warming of the climate in the succeeding intervals corresponding with pollen samples 13-25. No such analyses were carried out for the lower part of the sediment section corresponding with samples $1-7$. The pollen record does not suggest a gradual increase in temperature from sample 13 upwards. On the contrary, the evidence rather points to a cooler climate in the period covered by the uppermost part of the diagram (spectra 21-25).

\section{Oxygen isotope stages}

With respect to oxygen isotope stages (OIS) 18-20 determined for the GBY sediment section, the following may be remarked. Even-numbered isotope stages represent glacial periods with reduced temperatures, whereas interglacial periods, with higher temperatures, correspond with oddnumbered isotope stages. It has long been assumed that in the Mediterranean, due to the deflection of moist westerlies southwards by the presence of large ice sheets in northern Europe, pluvial conditions prevailed during glacial periods. 
Interglacials would have been characterized by warm and dry climatic conditions. Numerous palaeoenvironmental studies in the Mediterranean have led to the conclusion that the notion of wet glacial and dry interglacial periods needs to be re-evaluated. Dry and wet phases could occur in glacial as well as interglacial periods (cf. Tzedakis 2007). The GBY pollen record complies fairly well with this conclusion. It looks as though interglacial OIS 19 was a moderately moist period, with one arid interval. Glacial OIS 20, as far as represented in the GBY sediment section, was certainly not a wet period, with evidence of a distinctly arid phase (spectrum 7). Conditions of increased humidity are suggested for the lower part of glacial OIS 18, shown in the pollen diagram.

Acknowledgments The co-operation of various people in the preparation of the present paper is gratefully acknowledged. Naama Goren-Inbar has been most helpful in getting the preparatory work for the publication started by providing information on the site and relevant literature and by patiently responding to many questions. Information on the samples was received from Craig S. Feibel. Adam Walanus made an important contribution by executing the pollen diagram. Siebe E. Boersma prepared the drawing of Fig. 1. Mention is made here of the collaboration of Uri Baruch. Valuable comments on various drafts of the manuscript were received from Shoshana Ashkenazi, René T.J. Cappers, Mordechai E. Kislev and the reviewers Neil Roberts and P.C. Tzedakis. The English text was linguistically improved by John R.G. Daniell.

Open Access This article is distributed under the terms of the Creative Commons Attribution Noncommercial License which permits any noncommercial use, distribution, and reproduction in any medium, provided the original author(s) and source are credited.

\section{References}

Baruch U, Bottema S (1991) Palynological evidence for climatic changes in the Levant ca. 17,000-9,000 B.P. In: Bar-Yosef O, Valla FR (eds) The Natufian culture in the Levant. International Monographs in Prehistory, Archaeological Series 1, Ann Arbor, pp 11-20

Baruch U, Bottema S (1999) A new pollen diagram from Lake Hula. Vegetational, climatic and anthropogenic implications. In: Kanawabe H, Coulter GW, Roosevelt AC (eds) Ancient lakes. Their cultural and biological diversity. Kenobi Productions, Belgium, pp 75-86

Bottema S (2001) A note on the pollen representation of ivy (Hedera helix L.). Rev Palaeobot Palynol 117:159-166

Bottema S, Woldring H (1984) Late Quaternary vegetation and climate of southwestern Turkey, part II. Palaeohistoria 26:123-149

Danin A (2004) Distribution atlas of plants in the Flora Palaestina area. The Israel Academy of Sciences and Humanities, Jerusalem

Davis PH (ed) (1965-2000) Flora of Turkey and the East Aegean Islands. vol VI (1978), vol VII (1982). Edinburgh University Press, Edinburgh
Flora Palaestina (1966-1986) Vols. I (1966) and II (1972) by Zohary M, vols. III (1978) and IV (1986) by Feinbrun-Dothan N. The Israel Academy of Sciences and Humanities, Jerusalem

Goren-Inbar N, Feibel CS, Verosub KL, Melamed Y, Kislev ME, Tchernov E, Saragusti I (2000) Pleistocene milestones on the Out-of-Africa corridor at Gesher Benot Ya'aqov, Israel. Science 289:944-947

Goren-Inbar N, Sharon G, Melamed Y, Kislev M (2002a) Nuts, nut cracking, and pitted stones at Gesher Benot Ya'aqov, Israel. Proc Natl Acad Sci 99:2455-2460

Goren-Inbar N, Werker E, Feibel CS (2002b) The Acheulian site of Gesher Benot Ya'aqov Israel. The wood assemblage. Oxbow Books, Oxford

Goren-Inbar N, Alperson N, Kislev ME, Simchoni O, Melamed Y, Ben-Nun A, Werker E (2004) Evidence of hominin control of fire at Gesher Benot Ya'aqov, Israel. Science 304:725-727

Horowitz A (1979) The quaternary of Israel. Academic Press, New York

Horowitz A (2001) The Jordan rift valley. Balkema, Lisse Abingdon

Melamed Y (2004) Water plants as a food resource for ancient man at Gesher Benot Ya'akov. Abstract in: 13th Symposium of the International Work Group for Palaeoethnobotany, Girona

Nahal I (1962) Contribution à l'étude de la végétation dans le BaerBassit et le Djebel Alaouite de Syrie. Webbia 16:477-641

Post GE, Dinsmore JE (1932) Flora of Syria, Palestine and Sinai. 2 Vols. American University, Beirut

Rosenfeld A, Nathan Y, Feibel CS, Schilman B, Halicz L, GorenInbar N, Siman-Tov R (2003) Palaeoenvironment of the Acheulian Gesher Benot Ya'aqov Pleistocene lacustrine strata, northern Israel-lithology, ostracod assemblages and ostracod shell geochemistry. J Afr Earth Sci 38:169-181

Tzedakis PC (2007) Seven ambiguities in the Mediterranean palaeoenvironmental narrative. Q Sci Rev 26:2042-2066

Van Zeist W, Bottema S (1977) Palynological investigations in western Iran. Palaeohistoria 19:19-85

Waisel Y (1980) Trees of the land of Israel. Division of Ecology Ltd, Tel Aviv

Walanus A, Nalepka D (1999) POLPAL program for counting pollen grains, diagrams plotting and numerical analysis. Acta Palaeobot Suppl 2:659-661

Weinstein-Evron M (1983) The palaeoecology of the early Würm in the Hula Basin, Israel. Paléorient 9:5-19

Weinstein-Evron M, Lev-Yadun S (2000) Palaeoecology of Pinus halepensis in Israel in the light of palynological and archaeobotanical data. In: Ne'eman G, Trabaud L (eds) Biogeography and management of Pinus halepensis and P. brutia forest ecosystems in the Mediterranean Basin. Backhuys Publishers, Leiden, pp 119-130

Zohary M (1962) The plant life of Palestine (Israel and Jordan). Chronica Botanica, N.S. 33. The Ronald Press Co, New York

Zohary M (1973) Geobotanical foundations of the Middle East. 2 vols. Gustav Fischer/Swets and Zeitlinger, Stuttgart/Amsterdam

Zohary M (1982a) Vegetation of Israel and adjacent areas. Beihefte zum Tübinger Atlas des Vorderen Orients A7. Reichert, Wiesbaden

Zohary M (1982b) Plants of the Bible. University Press, Cambridge Zohary D, Hopf M (2000) Domestication of plants in the Old World, 3rd edn. University Press, Oxford 